\title{
Message From the Editor-in-Chief
}

\author{
Toyoaki Murohara, MD, PhD
}

Dear Colleagues,

On behalf of the Circulation Journal, I would like to let you know the 35 most frequently cited papers among the 19,854 papers published in the Japanese Circulation Journal (1968-2001) and Circulation Journal (2002-2016) (numbers in parentheses denote the number of citations).

1. (671) Matsuzawa Y, Nakamura T, Takahashi M, Ryo M, Inoue S, Ikeda Y, et al. New criteria for 'obesity disease' in Japan. Circ J 2002; 66: 987-992. (Review)

2. (383) Ryo M, Nakamura T, Kihara S, Kumada M, Shibazaki S, Takahashi M, et al. Adiponectin as a biomarker of the metabolic syndrome. Circ J 2004; 68: 975-981.

3. (323) Libby P, Okamoto Y, Rocha VZ, Folco E. Inflammation in atherosclerosis: Transition from theory to practice. Circ J 2010; 74: 213-220. (Review)

4. (267) Kitabatake A, Inoue M, Asao M, Tanouchi J, Masuyama T, Abe H, et al. Transmitral blood flow reflecting diastolic behavior of the left ventricle in health and disease: A study by pulsed Doppler technique. Jpn Circ J 1982; 46: 92-102.

5. (258) Zhou Q, Liao JK. Pleiotropic effects of statins: Basic research and clinical perspectives. Circ J 2010; 74: 818-826. (Review)

6. (227) Higashi Y, Noma K, Yoshizumi M, Kihara Y. Endothelial function and oxidative stress in cardiovascular diseases. Circ J 2009; 73: 411-418. (Review)

7. (213) Vanhoutte PM. Endothelial dysfunction: The first step toward coronary arteriosclerosis. Circ J 2009; 73: 595-601. (Review)

8. (209) Hamano K, Nishida M, Hirata K, Mikamo A, Li TS, Harada M, et al. Local implantation of autologous bone marrow cells for therapeutic angiogenesis in patients with ischemic heart disease: Clinical trial and preliminary results. Jpn Circ J 2001; 65: 845-847.

9. (197) Kawai S, Suzuki H, Yamaguchi H, Tanaka K, Sawada H, Aizawa T, et al. Ampulla cardiomyopathy ('Takotusbo' cardiomyopathy): Reversible left ventricular dysfunction with ST segment elevation. Jpn Circ J 2000; 64: 156-159.

10. (176) Jeong JW, Jeong MH, Yun KH, Oh SK, Park EM, Kim YK, et al. Echocardiographic epicardial fat thickness and coronary artery disease. Circ J 2007; 71: 536-539.

(176) Ueyama T, Kasamatsu K, Hano T, Yamamoto K, Tsuruo Y, Nishio I. Emotional stress induces transient left ventricular hypocontraction in the rat via activation of cardiac adrenoceptors: A possible animal model of 'takotsubo' cardiomyopathy. Circ J 2002; 66: 712-713.

12. (165) Lee HY, Oh BH. Aging and arterial stiffness. Circ J 2010; 74: 2257-2262. (Review)

13. (163) Yoo TW, Sung KC, Shin HS, Kim BJ, Kim BS, Kang JH, et al. Relationship between serum uric acid concentration and insulin resistance and metabolic syndrome. Circ J 2005; 69: 928-933.

14. (162) Hori M, Matsumoto M, Tanahashi N, Momomura S, Uchiyama S, Goto S, et al; on behalf of the J-ROCKET AF study investigators. Rivaroxaban vs. warfarin in Japanese patients with atrial fibrillation: The J-ROCKET AF Study. Circ J 2012; 76: 2104-2111.

15. (158) Ehara M, Surmely JF, Kawai M, Katoh O, Matsubara T, Terashima M, et al. Diagnostic accuracy of 64-slice computed tomography for detecting angiographically significant coronary artery stenosis in an unselected consecutive patient population: Comparison with conventional invasive angiography. Circ $J$ 2006; 70: $564-571$.

16. (155) Ando J, Yamamoto K. Vascular mechanobiology: Endothelial cell responses to fluid shear stress. Circ J 2009; 73: 1983 - 1992. (Review)

Released online September 13, 2017

Department of Cardiology, Nagoya University Graduate School of Medicine, Nagoya, Japan

Mailing address: Toyoaki Murohara, MD, PhD, Department of Cardiology, Nagoya University Graduate School of Medicine, 65 Tsurumai, Showa-ku, Nagoya 466-8550, Japan. E-mail: murohara@med.nagoya-u.ac.jp

ISSN-1346-9843 All rights are reserved to the Japanese Circulation Society. For permissions, please e-mail: cj@j-circ.or.jp 
17. (148) Fujita K, Nishizawa H, Funahashi T, Shimomura I, Shimabukuro M. Systemic oxidative stress is associated with visceral fat accumulation and the metabolic syndrome. Circ J 2006; 70: 1437-1442.

18. (141) Ogura R, Hiasa Y, Takahashi T, Yamaguchi K, Fujiwara K, Ohara Y, et al. Specific findings of the standard 12-lead ECG in patients with 'Takotsubo' cardiomyopathy: Comparison with the findings of acute anterior myocardial infarction. Circ J 2003; 67: 687-690.

(141) Aoki K, Yamori Y, Ooshima A, Okamoto K. Effects of high or low sodium intake in spontaneously hypertensive rats. Jpn Circ J 1972; 36: 539-545.

20. (139) Matsuzaki M, Kita T, Mabuchi H, Matsuzawa Y, Nakaya N, Oikawa S, et al. Large scale cohort study of the relationship between serum cholesterol concentration and coronary events with low-dose simvastatin therapy in Japanese patients with hypercholesterolemia: Primary prevention cohort study of the Japan Lipid Intervention Trial (J-LIT). Circ J 2002; 66: 1087-1095.

21. (134) Yamori Y, Nagaoka A, Okamoto K. Importance of genetic factors in stroke: An evidence obtained by selective breeding of stroke-prone and -resistant SHR. Jpn Circ J 1974; 38: 1095-1100.

22. (130) Tomiyama H, Koji Y, Yambe M, Shiina K, Motobe K, Yamada J, et al. Brachial-ankle pulse wave velocity is a simple and independent predictor of prognosis in patients with acute coronary syndrome. Circ J 2005; 69: 815-822.

(130) Ishikura K, Yamada N, Ito M, Ota S, Nakamura M, Isaka N, et al. Beneficial acute effects of Rho-kinase inhibitor in patients with pulmonary arterial hypertension. Circ J 2006; 70: 174-178.

24. (122) Shokawa T, Imazu M, Yamamoto H, Toyofuku M, Tasaki N, Okimoto T, et al. Pulse wave velocity predicts cardiovascular mortality: Findings from the Hawaii-Los Angeles-Hiroshima study. Circ J 2005; 69: $259-264$.

(122) Nakamura K, Tomaru T, Yamamura S, Miyashita Y, Shirai K, Noike H. Cardio-ankle vascular index is a candidate predictor of coronary atherosclerosis. Circ J 2008; 72: 598-604.

26. (119) Kawai S, Kitabatake A, Tomoike H; Takotsubo Cardiomyopathy Study Group. Guidelines for diagnosis of Takotsubo (ampulla) cardiomyopathy. Circ J 2007; 71: 990-992.

(119) Kawai C. Idiopathic cardiomyopathy: A study on the infectious-immune theory as a cause of disease. Jpn Circ J 1971; 35: 765-770.

28. (114) Kurisu S, Inoue I, Kawagoe T, Ishihara M, Shimatani Y, Nakamura S, et al. Time course of electrocardiographic changes in patients with tako-tsubo syndrome: Comparison with acute myocardial infarction with minimal enzymatic release. Circ $J$ 2004; 68: 77-81.

29. (113) Shimomura H, Terasaki F, Hayashi T, Kitaura Y, Isomura T, Suma H. Autophagic degeneration as a possible mechanism of myocardial cell death in dilated cardiomyopathy. Jpn Circ J 2001; 65: 965-968.

(113) Shimokawa H. Cellular and molecular mechanisms of coronary artery spasm: Lessons from animal models. Jpn Circ J 2000; 64: 1-12. (Review)

31. (112) Shibata R, Ouchi N, Murohara T. Adiponectin and cardiovascular disease. Circ J 2009; 73: 608 -614. (Review)

32. (110) Angiolillo DJ, Ueno M, Goto, S. Basic principles of platelet biology and clinical implications. Circ J 2010; 74: 597-607. (Review)

(110) Yamori Y. Pathogenesis of spontaneous hypertension as a model for essential hypertension. Jpn Circ J 1977; 41: 259-266.

34. (109) Tomiyama H, Yamashina A. Non-invasive vascular function tests: Their pathophysiological background and clinical application. Circ J 2010; 74: 24-33. (Review)

35. (106) Kajiguchi M, Kondo T, Izawa H, Kobayashi M, Yamamoto K, Shintani S, et al. Safety and efficacy of autologous progenitor cell transplantation for therapeutic angiogenesis in patients with critical limb ischemia. Circ J 2007; 71: 196-201.

The Editorial Team looks forward to receiving manuscripts with high scientific impact from all over the world.

Toyoaki Murohara, MD, $\mathrm{PhD}$

Editor-in-Chief

Circulation Journal 